\title{
Closing Red-light Areas Causing Uncontrollable Dispersals of Sex-workers in the Community of East-Java, Indonesia
}

\author{
Myrtati D. Artaria ${ }^{1}$, Sri E. Kinasih ${ }^{1}$, Pudjio Santoso ${ }^{1}$, Pinky S. E. Pratiwi ${ }^{1}$, and Sharyn G. Davies ${ }^{2}$ \\ ${ }^{1}$ Department of Anthropology, FISIP, Universitas Airlangga, Surabaya, Indonesia \\ ${ }^{2}$ Auckland University of Technology, Auckland, New Zealand
}

\begin{abstract}
In Indonesia, reducing the number of people having HIV/AIDS to $0.5 \%$ is one of Millennium Development Goals (MDGs). The recent policies resulted on the closing of six red-light areas in East Java. This research was intended to know what happened after the closing of red-light areas by the government. The researchers conducted a descriptive research applying qualitative approach. The stages of this research consisted of: 1) determining research locations purposively. This research was conducted in six red-light areas: Dupak Bangunsari, Tambak Asri, Moroseneng, Kalakah Rejo, and Dolly. 2) data collection process, consisting of observation and in-depth interview; 3) data analysis, data were classified into themes and being analyzed. The finding of this research indicates that there are new and different forms of prostitution activities conducted by the prostitutes in Surabaya. Prostitution activities are conducted secretly and camouflaged.
\end{abstract}

Keywords: Sex worker, red-light areas

\section{Introduction}

Health development aims to improve health quality of the society. In order to achieve high health quality, the role of women as agent of health in a family is vital [1] to assure their children grow healthy until reaching adulthood. Therefore, women need more attention than men because women experience specific health issues related to their reproductive function which is different from men reproductive function. In Indonesia, reducing the number of people having HIV/AIDS to $0.5 \%$ is one of Millennium Development Goals (MDGs). The recent policies resulted on the closing of six red-light areas in East Java. There is an evidence of increasing human trafficking when prostitution is legalized [2]. However, when it is illegal, would it have side affects too? This research was intended to know what happened after the closing of red-light areas by the government.

\section{Methods}

The researchers conducted a descriptive research applying qualitative approach. The stages of this research consisted of:

- first, determining research locations purposively. This research was conducted in six red-light areas, in Dupak Bangunsari, Tambak Asri, Moroseneng, Kalakah Rejo, and Dolly. These areas were "hotspots" of red-light areas in Surabaya which had been operated for a long period. We suspect that these areas became the centers of HIV/AIDS transmission in Surabaya.

- Second, the data collection process consisted of observation and in-depth interview. There were 20 informants consisting of sex workers and former sex-workers who have health problems related to HIV and AIDS; the Head of Local Health Center, NGO in those areas, and midewives.

- Third, data analysis by classifying into themes and then the data were analyzed. The interpretation were made by giving meaning to the themes and sub-themes, and by correlating the data.

\section{Results and Discussion}

The closing of four red-light areas in Surabaya: Sememi (Moroseneng), Klakah Rejo, Tambak Asri (Kremil), and Dupak Bangunsari had been planned by Surabaya government since early 1990s [3]. This means 
Surabaya government owns a legal basis - the Local Government Regulation Number 7/1999, to prevent utilization of any building in Surabaya as prostitution location. According to Surabaya Social Agency (Dinas Sosial Kota Surabaya), the closing of four red-light districts had been accepted and decided by religious leaders and public figures in these areas. As it has been stated by Bernardin [4] that religious leader may have important roles in decision in the public policy.

The closing of Sememi, Klakah Rejo, Tambak Asri, and Dupak Bangunsari were very easy. The closing were coincided with religious recitation attended by Surabaya Mayor, Tri Rismaharini. Religious recitation is an activity that is often held by the society every week, in most Islamic religion communities in Indonesia. The support of religious people can be used to reinforce the plan of the government to complete the action of closing the red-light areas. Using religion to legitimate an action by a government has been done before, even for a long time; such as related to health issues as stated by Campbell et al. [5].

There was no specific sanction for the sex workers or specific preparation made by Surabaya government. After the closing, those who conducted prostitution practice would be warned and subjected to criminal law. Using law as inforcement of banning red-light areas has been done in several places such as Ireland, Iceland, and Malta [6], and Sweden [7].

The closing of Dolly and Jarak were very difficult compared to other four red-light areas (Dupak Bangunsari, Klakah Rejo, Sememi, and Tambak Asri). In these four areas, the sex workers were poor. Hence, they needed and were satisfied with the compensation money provided by the government. In the contrary, the sex workers in Jarak and Dolly were richer and had a strong network. They did not need compensation money provided by the Surabaya Government. This situation often caused conflicts between Surabaya government and the sex workers. Explicitly, the sex workers declared their rejection on government plan to close the prostitution area. However these action failed and the closing of the areas were finally realized.

According to our informants and our observation, in order to find income as much as they had before, several sex-workers tried to survive by obtaining their old consumers, but they stay in regular boarding houses mingled with other workers around and outside the old red-areas. Some others tried to maintain good relationship with the old pimps and operate illegally in more spread out places.

\section{Conclusion}

Because of the warning that continuing sex business in those areas above is illegal, the sex workers want to continue their business secretly. The finding of this research indicates that there are new and different forms of prostitution activities conducted by the prostitutes in Surabaya. After the closing of the red-areas above, the prostitution activities are conducted secretly and camouflaged. This can be a bigger problem for the government for managing the spread of HIV/AIDS, that previously had been in a better control within the red-light areas.

\section{Acknowledgements}

We would like to thank the Government of Indonesia for giving us the PUPT grant for conducting this research.

\section{References}

[1] A. Rahman, P. J. Surkan, C. E. Cayetano, P. Rwagatare, K. E. Dickson, "Grand challenges: integrating maternal mental health into maternal and child health programmes," PLoS Med. May 7;10(5):e1001442, 2013.

[2] S. Y. Cho, A. Dreher, \& E. Neumayer, "Does legalized prostitution increase human trafficking?" World Development, Vol. 41, pp. 67-82, 2013.

https://doi.org/10.1016/j.worlddev.2012.05.023

[3] https://www.merdeka.com/peristiwa/ini-alasan-risma-tutup-lokalisasi-gang-dolly-mati-matian.html. Accessed 26 September 2016. Newspaper online. 
[4] J. C. Bernardin, "Role of the Religious Leader in the Development of Public Policy," Journal of Law and Religion, Vol. 2(2), pp. 369-379, 1984.

https://doi.org/10.2307/1051097

[5] M. K. Campbell, M. A. Hudson, K. Resnicow, N. Blakeney, A. Paxton, \& M. Baskin, "Church-based health promotion interventions: evidence and lessons learned," Annu. Rev. Public Health, Vol. 28, pp. 213-234, 2007. https://doi.org/10.1146/annurev.publhealth.28.021406.144016

[6] J. R. Hibbeln, "Fish consumption and major depression," Lancet, Vol. 351(9110), p. 1213, 1998. https://doi.org/10.1016/S0140-6736(05)79168-6

[7] G. Ekberg, "The Swedish Law that Prohibits the Purchase of Sexual Services Best Practices for Prevention of Prostitution and Trafficking in Human Beings," Violence Against Women, Vol. 10(10), pp. 1187-1218, 2004. https://doi.org/10.1177/1077801204268647 